\title{
Gene expression of Aspergillus flavus strains on a cheese model system to control aflatoxin production
}

\author{
Rocío Casquete, ${ }^{1,2}$ María José Benito, ${ }^{1,2 *}$ Emilio Aranda, ${ }^{1,2}$ Alberto Martín, ${ }^{1,2}$ Santiago Ruiz-Moyano, ${ }^{1,2}$ \\ and María de Guía Córdoba ${ }^{1,2}$ \\ ${ }^{1}$ Nutrición y Bromatología, Escuela de Ingenierías Agrarias, Universidad de Extremadura, Avd. Adolfo Suárez s/n, 06007 Badajoz, Spain \\ ${ }^{2}$ Instituto Universitario de Investigación en Recursos Agrarios (INURA), Universidad de Extremadura, Avd. De la Investigación, 06006 Badajoz, \\ Spain
}

\section{ABSTRACT}

The expression of genes associated with aflatoxin biosynthesis by different Aspergillus flavus strains growing on a cheese model system has not been studied. To control aflatoxin biosynthesis, it would be useful to understand the changes in gene expression during cheesemaking and relate those changes to toxin production. The objective of this study was to evaluate the effects of $\mathrm{pH}$, water activity, and temperature on the expression of 2 regulatory genes (aftR and aflS) and 1 structural gene (aflP) involved in aflatoxin biosynthesis, using 3 aflatoxigenic A. flavus strains growing on a cheese-based medium and reverse-transcription realtime PCR. The gene expression patterns were influenced by $A$. flavus strain and environmental conditions. The structural gene aflP and the regulatory genes aftR and aftS showed similar expression patterns in each $A$. flavus strain, but we also observed inter-strain differences. We observed the highest expression levels at 6 and $9 \mathrm{~d}$ of incubation by $A$. flavus strains CQ8 and CQ103, and saw a decrease in the days following. Strain CQ7 showed the lowest expression of these genes. We observed the highest expression levels of these genes at $\mathrm{pH} 5.5$, water activity 0.95 , and 20 to $25^{\circ} \mathrm{C}$; strain CQ103 showed a different pattern for the aflS gene, with maximum expression at $\mathrm{pH} 6.0$ on $\mathrm{d} 6$ of incubation. For the 3 strains, we found a strong correlation between the relative expression of the aftR and aflS genes and the concentration of aflatoxins under conditions that simulated cheese ripening. Control strategies to avoid aflatoxin contamination during cheesemaking could use the detection of regulatory gene expression. Key words: aflatoxin, Aspergillus flavus, ripened cheese, gene expression

Received April 1, 2019.

Accepted May 14, 2019.

*Corresponding author: mjbenito@unex.es

\section{INTRODUCTION}

Aspergillus flavus is among the most important toxigenic mold species that produce aflatoxins (Bhatnagar et al., 2006). These mycotoxins are secondary metabolites that filamentous fungi can produce in foods under appropriate environmental conditions. Although A. flavus grows and produces mycotoxins at a wide range of temperatures and water activities $\left(\mathbf{a}_{\mathrm{w}}\right)$, the ideal temperature for aflatoxin production is 28 to $30^{\circ} \mathrm{C}$; production decreases dramatically below $25^{\circ} \mathrm{C}$ and approaching $37^{\circ} \mathrm{C}$. Better fungal growth and toxin production are also detected at higher $\mathrm{a}_{\mathrm{w}}$ levels: growth and spore germination rates slow at $\mathrm{a}_{\mathrm{w}}<0.85$ (Schmidt-Heydt et al., 2009; Abdel-Hadi et al., 2012). The aflatoxins $\mathrm{AFB}_{1}$ and $\mathrm{AFB}_{2}$ are produced mainly by Aspergillus flavus, but $\mathrm{AFB}_{1}$ is produced in higher amounts than the other aflatoxins, and it is considered to be the most potent natural hepatocarcinogen characterized to date (Wogan, 1992; Groopman and Kensler, 2005).

Although A. flavus normally contaminates maize, cereals, spices, and dried fruit (Arrus et al., 2005; Molyneux et al., 2007; Zinedine et al., 2007; HernándezHierro et al., 2009; Astoreca et al., 2012), its presence in cheese has been reported by several authors (Barrios et al., 1997; De Santi et al., 2010; Baranyi et al., 2015). As such, mycotoxins $\mathrm{AFB}_{1}, \mathrm{AFB}_{2}, \mathrm{AFG}_{1}$, and $\mathrm{AFG}_{2}$ have all been detected in cheeses (Taniwaki et al., 2001). Apart from these reports, however, few studies have documented the occurrence of aflatoxins as a result of mold contamination in cheese.

Recent studies have investigated how the activation rate and regulation of aflatoxin biosynthesis genes are affected by variations in temperature and $a_{w}$ (Gallo et al., 2016; Bernáldez et al., 2017; Peromingo et al., 2017). The production of aflatoxins is always preceded by expression of the genes involved in the aflatoxin biosynthetic pathway. The key regulatory genes involved in aflatoxin production as a cluster are aftR and aflS (Abdel-Hadi et al., 2011). The aftR gene encodes a 
protein required for transcriptional activation of most of the structural genes in the aflatoxin biosynthetic pathway (Georgianna and Payne, 2009); the function of the aflS gene is still unclear.

Studies have produced conflicting results about the role of aflS and aftR transcription as determinants of aflatoxin biosynthesis (Schmidt-Heydt et al., 2009, 2010; Abdel-Hadi et al., 2011; Yu et al., 2011; Zhang et al., 2014). Gallo et al. (2016) found that aftR and aflS were highly expressed at maximum and minimum $\mathrm{AFB}_{1}$ production.

Even so, the sterigmatocystin-o-methyltransferase gene (aflP), a structural gene demonstrated to be necessary for aflatoxin production (Rodríguez et al., 2012), is activated by the aftR gene product (Sweeney et al., 2000). Therefore, the expression of both regulatory and structural genes could be good indicators of aflatoxin production under different environmental conditions during the ripening of cheeses.

The expression of genes associated with aflatoxin biosynthesis by different $A$. flavus strains growing on a cheese model system has not been studied. Understanding changes in gene expression related to toxin production during cheesemaking might allow for the design of control strategies to prevent product contamination.

The aim of this study was to evaluate the effect of $\mathrm{pH}, \mathrm{a}_{\mathrm{w}}$, and temperature on the expression of 2 regulatory genes (aftR and aflS) and 1 structural gene (aflP) involved in aflatoxin biosynthesis, using 3 aflatoxigenic A. flavus strains on a cheese-based medium and reversetranscription real-time quantitative PCR.

\section{MATERIALS AND METHODS}

\section{Fungal Strains}

We used A. flavus CQ7, A. flavus CQ8, and A. flavus CQ103 - 3 strains that produce $\mathrm{AFB}_{1}$ and $\mathrm{AFB}_{2}-$ isolated from a vegetable coagulant typical of the Mediterranean area (Cynara cardunculus L.) that has been used for cheesemaking (Casquete et al., 2017).

\section{Inocula Preparation}

The strains were initially grown on malt extract agar (Scharlab S.L., Barcelona, Spain) at $25^{\circ} \mathrm{C}$ for 7 d. A spore suspension of each strain was collected by adding $10 \mathrm{~mL}$ of sterile $0.05 \%$ ( $\mathrm{vol} / \mathrm{vol}$ ) Tween 80 (Scharlab S.L.) to each mold plate and then rubbing the surface with a glass rod. The suspension formed was filtered through 2 layers of cheesecloth. The concentration of each spore suspension was quantified using a Neubauer chamber and a microscope (Olympus CX 400, Tokyo,
Japan), and adjusted to $10^{5}$ spores $/ \mathrm{mL}$ with sterile water.

\section{Experimental Settings}

The cheese agar medium used in this study was prepared as described by Casquete et al. (2017). The $\mathrm{pH}$ of autoclaved basic medium was modified to 5.0, 5.5 , and 6.0 by addition of $0.2 \mu M$ filtered lactic acid. The medium was also modified by the addition of 286 , 193, 101, or $0 \mathrm{~mL}$ of glycerol (Scharlab S.L.) per liter of medium to obtain to $\mathrm{a}_{\mathrm{w}}$ of 0.90, 0.95, and 0.99, respectively. The $\mathrm{a}_{\mathrm{w}}$ of the cheese agar medium was confirmed by using a Novasina LabMaster $\mathrm{a}_{\mathrm{w}}$ meter (AG Lachen, Switzerland). Following the additions, the cheese agar was then immediately poured into Petri dishes and allowed to solidify at room temperature. Initial experiments were performed at a fixed temperature $\left(25^{\circ} \mathrm{C}\right), 3 \mathrm{pH}$ levels $(5.0,5.5$, and 6.0$)$, and $\mathrm{a}_{\mathrm{w}}$ of 0.99 , as commonly encountered in cheese and cheese products. Then we fixed the $\mathrm{pH}$ of the medium at 5.0, with a temperature of $25^{\circ} \mathrm{C}$, to analyze the effects of different $\mathrm{a}_{\mathrm{w}}(0.90,0.95$, and 0.99$)$ on aflatoxin gene expression. Finally, we used media at conditions for maximum aflatoxin production ( $\mathrm{pH} 5.0$ and $0.95 \mathrm{a}_{\mathrm{w}}$ ) to assess the effect of temperature $\left(15,20,25\right.$, and $\left.30^{\circ} \mathrm{C}\right)$. The cheese agar medium was incubated for up to $12 \mathrm{~d}$ after the end of the lag phase. Samples were taken every $3 \mathrm{~d}$ (3, 6,9 , and 12 d) after inoculation. For each experiment and condition, 2 biological replicates and 3 technical replicates were performed.

\section{Gene Expression Studies}

Harvested biomass was stored at $-80^{\circ} \mathrm{C}$ until RNA was extracted. RNA was isolated using the Spectrum Plant Total RNA Kit (Sigma-Aldrich, St. Louis, MO). Samples of 250 to $500 \mathrm{mg}$ of mycelium biomass were ground to powder in a prefrozen mortar, and total RNA was purified as described in Peromingo et al. (2017). We used DNase I (Fermentas/Thermo Fisher Scientific, Leon-Rot, Germany) to remove genomic DNA contamination. A NanoDrop 2000c spectrophotometer (Thermo Fisher Scientific, Wilmington, DE) was used to determine RNA concentration and purity.

Gene expression studies were performed by using reverse-transcription real-time quantitative PCR. First, cDNA was synthesized using about $500 \mathrm{ng}$ of total RNA according to the PrimeScript RT Reagent kit protocol (Takara Bio Inc., Otsu, Shiga, Japan; https: //www.takarabio.com/products/real-time-pcr/reverse -transcription-prior-to-qpcr/primescript-rt-reagent -kit), and then used this for quantitative PCR analysis. 
Table 1. Nucleotide sequence of primers for real-time quantitative PCR assays

\begin{tabular}{|c|c|c|c|c|}
\hline Gene & Primer & Nucleotide sequence $\left(5^{\prime}-3^{\prime}\right)$ & Product size (bp) & Reference \\
\hline affP & $\begin{array}{l}\text { F-omt } \\
\text { R-omt }\end{array}$ & $\begin{array}{l}\text { GGCCGCCGCTTTGATCTAGG } \\
\text { ACCACGACCGCCGCC }\end{array}$ & 123 & Rodríguez et al., 2012 \\
\hline aflR & $\begin{array}{l}\text { AflRTaq1 } \\
\text { AflRTaq2 }\end{array}$ & $\begin{array}{l}\text { TCGTCCTTATCGTTCTCAAGG } \\
\text { ACTGTTGCTACAGCTGCCACT }\end{array}$ & 89 & Medina et al., 2015 \\
\hline aflS & $\begin{array}{l}\text { AflSqPCR1 } \\
\text { AflSqPCR2 }\end{array}$ & $\begin{array}{l}\text { TGGTGCGACCATATTTACA } \\
\text { GGTTGGGTCACGAACTGTTT }\end{array}$ & 94 & Peromingo et al., 2017 \\
\hline$\beta-T U B . J D$ & $\begin{array}{l}\text { F-TUBjd } \\
\text { R-TUBjd }\end{array}$ & $\begin{array}{l}\text { TCTTCATGGTTGGCTTCGCT } \\
\text { CTTGGGGTCGAACATCTGCT }\end{array}$ & 98 & Peromingo et al., 2017 \\
\hline
\end{tabular}

Primer pairs F/R-omt, AflRTaq1/2, and AflSqPCR1/2 were used to amplify the structural gene (aflP) and the regulatory genes (aftR and aflS), respectively (Peromingo et al., 2017); the primer pair F/R-TUBjd amplified the $\beta$-tubulin $(\beta-T U B . J D)$ gene, used as the endogenous control (Table 1$)$.

The qPCR reactions were carried out using an Applied Biosystems 7300 Fast Real-Time PCR system (Applied Biosystems, Foster City, CA). The assays were prepared in triplicate in MicroAmp optical 96-well reaction plates and sealed with optical adhesive covers (Applied Biosystems). The SYBR Green methodology was performed, using $6.25 \mu \mathrm{L}$ of SYBR Premix Ex Taq (Takara Bio Inc.), $0.05 \mu \mathrm{L}$ of $50 \times$ ROX Reference Dye (Takara Bio Inc.), $10 \mu M$ of each primer, and $2.5 \mu \mathrm{L}$ of each cDNA template in a final volume of $12.5 \mu \mathrm{L}$. A negative control without DNA was also included in every run. An initial denaturation step of $10 \mathrm{~min}$ at $95^{\circ} \mathrm{C}$ was followed by 40 cycles of $95^{\circ} \mathrm{C}$ for $15 \mathrm{~s}$ and $60^{\circ} \mathrm{C}$ for $30 \mathrm{~s}$. Melting curve analysis of the PCR products was performed by heating to 72 to $95^{\circ} \mathrm{C}$ and continuous measurement of the fluorescence to quantify the PCR product. We calculated the threshold cycle $(\mathrm{Ct})$ value, corresponding to the PCR cycle number at which fluorescence was detected above threshold, using 7300 Fast system SDS software (Applied Biosystems).

To avoid errors caused by the addition of different amounts of total cDNA to each reaction, we quantified the expression of the aftP, aftR, and aflS genes with the housekeeping gene $\beta$-TUB.JD as an endogenous expressed control. We calculated the expression ratio using the $2^{-\Delta \Delta \mathrm{Ct}}$ method (Livak and Schmittgen, 2001). The experimental treatments used in this study have been shown not to influence the expression of the internal control gene (Peromingo et al., 2017). Evaluating relative gene expression by reverse-transcription realtime quantitative PCR allows for determination of the expression ratio of a target gene between the tested sample and its relative calibrator ("control" sample). The amplification efficiencies of the target and reference genes were practically equal $(94.7 \%$ for the aflP gene, $99.5 \%$ for the aflR gene, $99.5 \%$ for the afl $S$ gene, and $86.6 \%$ for the $\beta$-TUB.JD gene). We used $A$. flavus samples incubated for $3 \mathrm{~d}$ as controls for temporal measurements of the expression of the aflP, aflR, and aflS genes.

\section{Extraction and Quantification of Aflatoxins}

We evaluated aflatoxin extraction and quantification by harvesting the biomass at $10 \mathrm{~d}$ after the end of the lag phase and storing it at $-20^{\circ} \mathrm{C}$ until the aflatoxin extraction procedure. We extracted aflatoxins from the fungal mycelium using the quick, easy, cheap, effective, rugged, and safe (QuEChERS) procedure (Casquete et al., 2017), with modifications. For this purpose, 2 agar plugs of $4 \mathrm{~mm}$ in diameter were placed in an extraction tube containing $200 \mathrm{mg}$ of $\mathrm{MgSO}_{4}$ and $50 \mathrm{mg}$ of NaOAc (Thermo Fisher Scientific). Then, $1 \mathrm{~mL}$ of HPLC-grade acetonitrile (Fisher Scientific) was added and the mixture was shaken vigorously for $2 \mathrm{~min}$, followed by sonication for $20 \mathrm{~min}$, and then centrifugation at $14,000 \times g$ at $25^{\circ} \mathrm{C}$ for $1 \mathrm{~min}$. The supernatant was transferred to a clean tube containing $75 \mathrm{mg}$ of $\mathrm{MgSO}_{4}$, $25 \mathrm{mg}$ of primary secondary amine (Sigma-Aldrich), and $25 \mathrm{mg}$ of C18 (Scharlab S.L.), and homogenized for $1 \mathrm{~min}$. The mixture was then centrifuged $(14,000$ $\left.\times g, 25^{\circ} \mathrm{C}, 1 \mathrm{~min}\right)$ and $400 \mu \mathrm{L}$ of the supernatant was filtered through a filter $(0.22 \mu \mathrm{m}$ pore size $)$ into vials for quantification.

The AF analysis was carried out using an Agilent 1100 Series HPLC system (Agilent Technologies, Santa Clara, CA) equipped with a diode array detector (G1315B; Agilent) set at $360 \mathrm{~nm}$ and using a C18 HPLC column $(250 \times 4.6 \mathrm{~mm}, 5 \mu \mathrm{m}$ particle size; Supelco, Bellefonte, PA). The mobile phase used for the separation contained HPLC-grade water (solvent A) and HPLC-grade acetonitrile (solvent B), run in a gradient mode set from $15 \% \mathrm{~B}$ at initiation to $100 \% \mathrm{~B}$ at 30 min. A 3-min period was necessary for column equilibration. All solvents used were purchased from Thermo Fisher Scientific (Runcorn, UK). The injection 
volume was $25 \mu \mathrm{L}$, and the flow rate was $1 \mathrm{~mL} / \mathrm{min}$ for all experiments. Calibrations were carried out for each aflatoxin using standards purchased from SigmaAldrich (St. Louis, MO).

\section{Statistical Analysis}

We conducted statistical analysis of the parameters using one-way ANOVA. The means were separated by Tukey's honestly significant difference test $(P \leq 0.05)$ in SPSS for Windows 21.0 (SPSS Inc., Chicago, IL). Levels of aflatoxins after $10 \mathrm{~d}$ of growth $\left(\mathrm{AFB}_{1}\right.$ and $\mathrm{AFB}_{2}$ ) were correlated with the temporal relative expression of the aftP, aftR, and aftS genes in A. flavus CQ7, CQ8, and CQ103. The results from the principal component analysis (PCA) were interpreted graphically by drawing biplots, in which scatter plots of the score matrix (points) and the loading matrix (arrows) for the first 2 components were superimposed for a condensed representation of the correlation between the original variables and the distribution of the samples. The statistical significance was set at $P \leq 0.05$.

\section{RESULTS AND DISCUSSION}

\section{Effect of $\mathrm{pH}, \mathrm{a}_{\mathrm{w}}$ and Temperature on the Relative Expression of Genes Involved in Aflatoxin Biosynthesis by A. flavus}

The involvement of abiotic factors in the activation of aflatoxin biosynthetic genes in different foods and synthetic food media has been previously studied, but not in a cheese model system. The effects of $\mathrm{pH}, \mathrm{a}_{\mathrm{w}}$, and temperature on the relative temporal gene expression of aftR, aflS, and aflP genes by the 3 aflatoxin-producing A. flavus strains are presented in Figure 1, Figure 2, and Table 2 .

In general, the expression patterns of the genes were influenced by environmental conditions. Because gene transcription occurs before toxin production, a temporal analysis of the expression of biosynthetic genes using real-time quantitative PCR, could help in taking early action to prevent aflatoxin production (Visentin et al., 2012; Rodríguez et al., 2014; Peromingo et al., 2017). Samples incubated for $3 \mathrm{~d}$ for each treatment were used

\section{A. flavus CQ8}
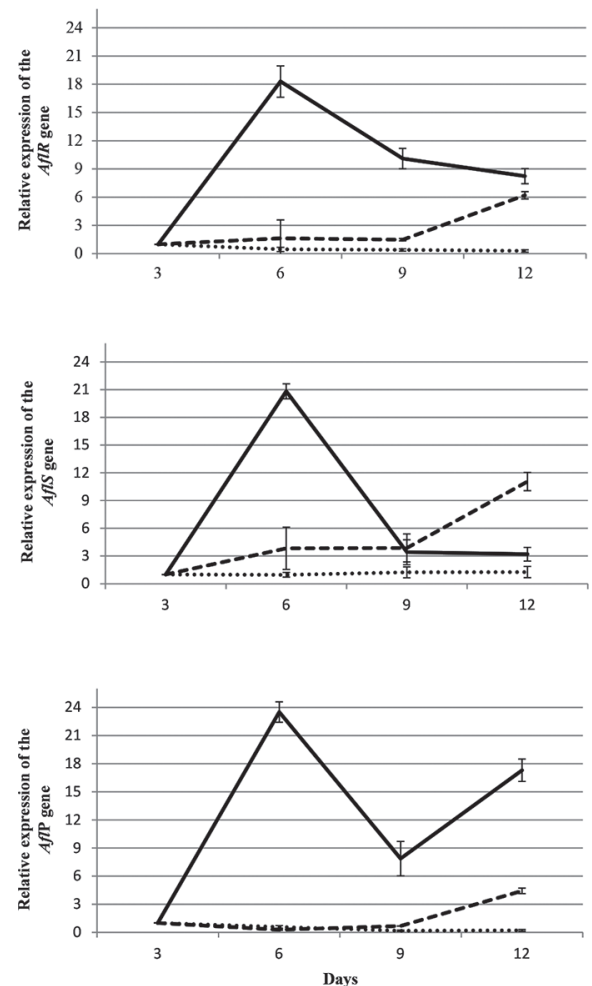

A. flavus CQ103
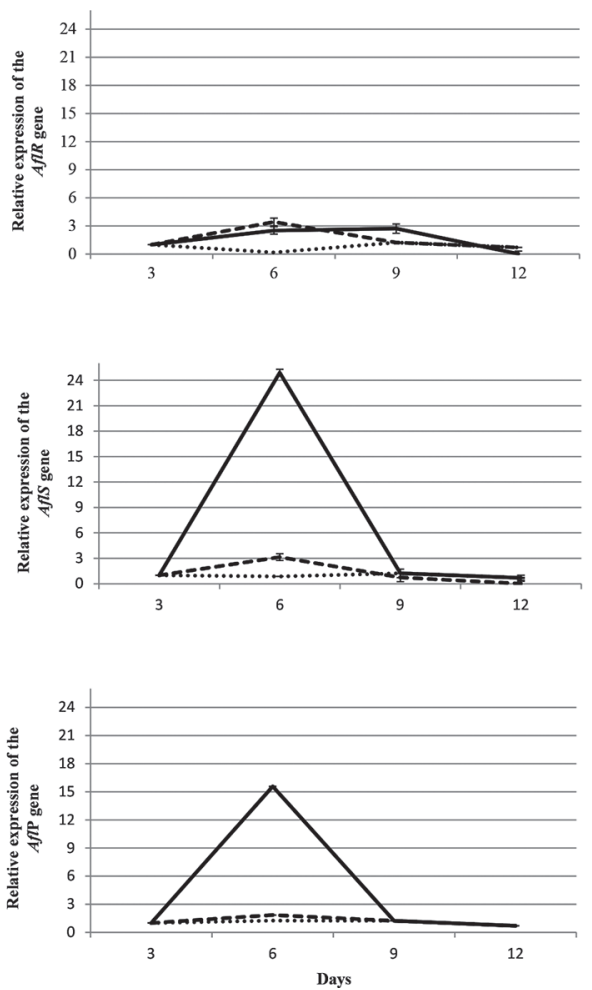

A. flavus CQ7
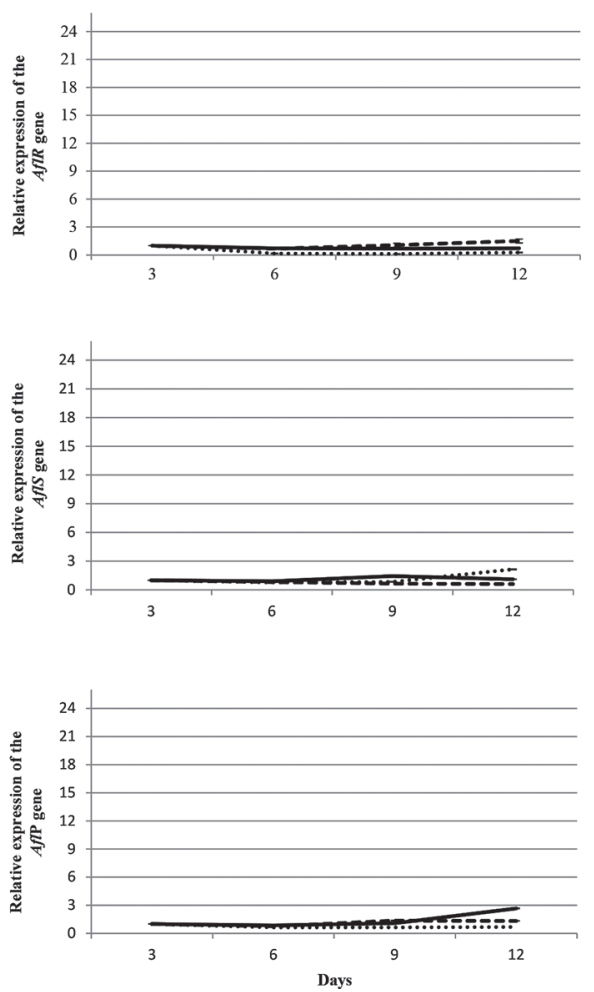

Figure 1. Effect of pH 5.0 (dotted line), 5.5 (solid line), and 6.0 (dashed line) on the temporal relative expression of aftR, aflS, and aftP genes by Aspergillus flavus grown on a cheese-based medium at a water activity level of 0.99 and a temperature of $25^{\circ} \mathrm{C}$ for $12 \mathrm{~d}$ after the end of the lag phase. The calibrator consisted of samples taken at d 3 of incubation and always had a value equal to 1 . Error bars represent the statistical standard error. 
A. flavus $\mathrm{CQ8}$
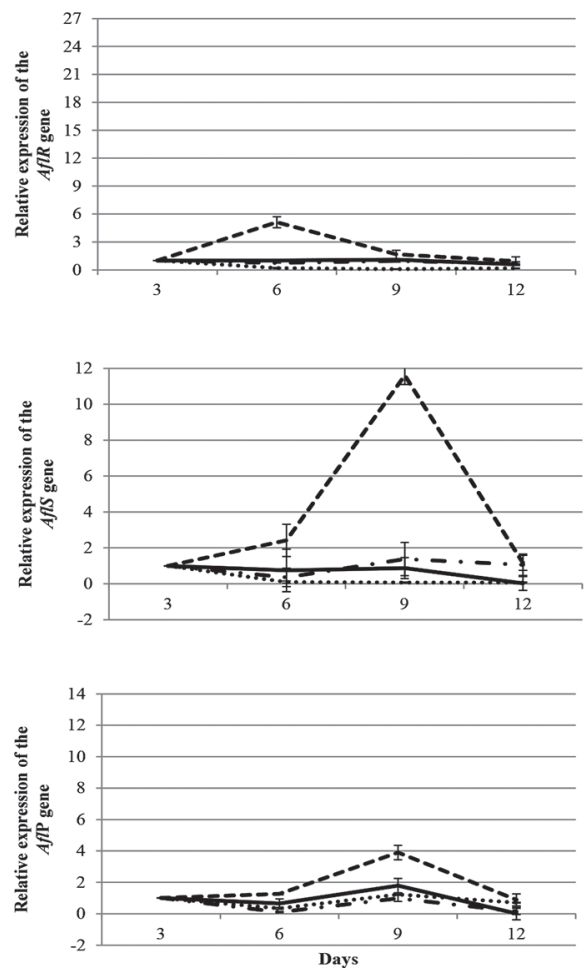

A. flavus $\mathrm{CQ103}$
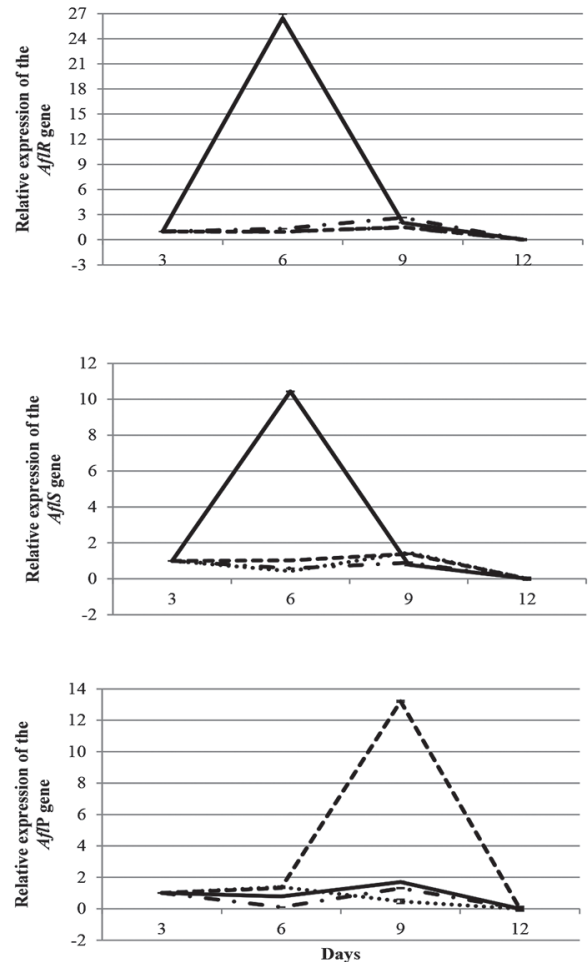

A. flavus CQ7
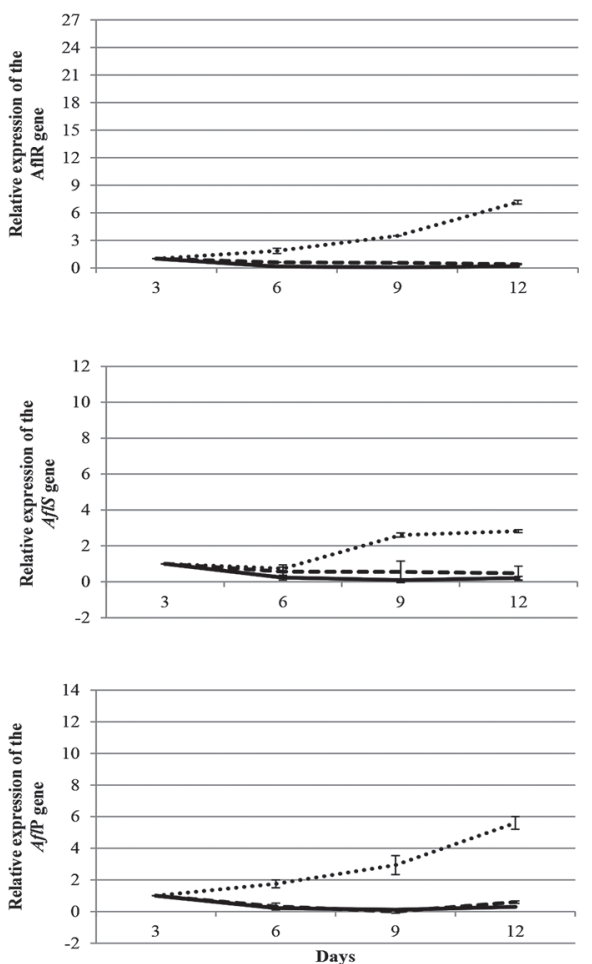

Figure 2. Effect of temperature $30^{\circ} \mathrm{C}$ (dotted line), $25^{\circ} \mathrm{C}$ (solid line), $20^{\circ} \mathrm{C}$ (dashed line), and $15^{\circ} \mathrm{C}$ (dot-dash line) on the temporal relative expression of aftR, aflS, and aflP genes by Aspergillus flavus grown on a cheese-based medium at a water activity level of 0.95 and a $\mathrm{pH}$ of 5.0 for $12 \mathrm{~d}$ after the end of the lag phase. The calibrator consisted of samples taken at d 3 of incubation and always had a value equal to 1 . Error bars represent the statistical standard error.

as calibrators; any expression before this time point was not considered in this study.

Figure 1 shows the effect of different $\mathrm{pH}$ levels (5.0, 5.5 , and 6.0) at an $\mathrm{a}_{\mathrm{w}}$ of 0.99 and a temperature of $25^{\circ} \mathrm{C}$ on the relative expression of aflatoxin biosynthesis genes
(aftR, aflS, and aflP) by A. flavus CQ8, CQ103, and CQ7 in a synthetic cheese medium during an incubation period of $12 \mathrm{~d}$. We evaluated the relative expression of the target genes at different sampling times and compared them with controls (A. flavus CQ8, CQ103, and

Table 2. Effect of water activity level $(0.99,0.95$, and 0.90$)$ on the temporal relative expression of the aftR, aflS, and aflP genes by Aspergillus flavus grown on a cheese-based medium at $\mathrm{pH} 5$ and $25^{\circ} \mathrm{C}$ for $12 \mathrm{~d}$

\begin{tabular}{|c|c|c|c|c|c|c|c|c|c|c|}
\hline $\begin{array}{l}\text { Gene } \\
\text { expression }\end{array}$ & Days & \multicolumn{3}{|c|}{ A. flavus CQ8 } & \multicolumn{3}{|c|}{ A. flavus CQ103 } & \multicolumn{3}{|c|}{ A. flavus CQ7 } \\
\hline \multirow[t]{3}{*}{ aflR } & 3 & $1.000^{\mathrm{a}}$ & $1.000^{\mathrm{a}}$ & $1.000^{\mathrm{a}}$ & $1.000^{\mathrm{a}}$ & $1.000^{\mathrm{a}}$ & $1.000^{\mathrm{a}}$ & $1.000^{\mathrm{a}}$ & $1.000^{\mathrm{a}}$ & - \\
\hline & 9 & $0.395^{\mathrm{a}}$ & $1.087^{\mathrm{a}}$ & $0.806^{\mathrm{a}}$ & $1.228^{\mathrm{a}}$ & $2.026^{\mathrm{a}}$ & $0.585^{\mathrm{a}}$ & $0.108^{\mathrm{a}}$ & $0.065^{\mathrm{a}}$ & - \\
\hline & 12 & $0.292^{\mathrm{a}}$ & $0.578^{\mathrm{a}}$ & $0.890^{\mathrm{a}}$ & $0.702^{\mathrm{a}}$ & $0.001^{\mathrm{a}}$ & $0.001^{\mathrm{a}}$ & $0.261^{\mathrm{a}}$ & $0.167^{\mathrm{a}}$ & - \\
\hline aflS & 3 & $1.000^{\mathrm{a}}$ & $1.000^{\mathrm{a}}$ & $1.000^{\mathrm{a}}$ & $1.000^{\mathrm{a}}$ & $1.000^{\mathrm{a}}$ & $1.000^{\mathrm{a}}$ & $1.000^{\mathrm{a}}$ & $1.000^{\mathrm{a}}$ & - \\
\hline \multirow[t]{4}{*}{ aflP } & 3 & $1.000^{\mathrm{a}}$ & $1.000^{\mathrm{a}}$ & $1.000^{\mathrm{a}}$ & $1.000^{\mathrm{a}}$ & $1.000^{\mathrm{a}}$ & $1.000^{\mathrm{a}}$ & $1.000^{\mathrm{a}}$ & $1.000^{\mathrm{a}}$ & - \\
\hline & 6 & $0.573^{\mathrm{a}}$ & $0.657^{\mathrm{a}}$ & $3.264^{\mathrm{b}}$ & $1.254^{\mathrm{a}}$ & $0.781^{\mathrm{a}}$ & $0.993^{\mathrm{a}}$ & $0.847^{\mathrm{a}}$ & $0.220^{\mathrm{a}}$ & - \\
\hline & 9 & $0.157^{\mathrm{a}}$ & $1.794^{\mathrm{a}}$ & $5.278^{\mathrm{b}}$ & $1.218^{\mathrm{a}}$ & $1.697^{\mathrm{a}}$ & $1.228^{\mathrm{a}}$ & $1.074^{\mathrm{a}}$ & $0.117^{\mathrm{a}}$ & - \\
\hline & 12 & $0.197^{\mathrm{a}}$ & $0.014^{\mathrm{a}}$ & $2.567^{\mathrm{b}}$ & $0.702^{\mathrm{a}}$ & $0.001^{\mathrm{a}}$ & $0.702^{\mathrm{a}}$ & $2.651^{\mathrm{b}}$ & $0.296^{\mathrm{a}}$ & - \\
\hline
\end{tabular}

${ }^{\mathrm{a}, \mathrm{b}}$ Values with different superscript letters were significantly different $(P<0.05)$ between water activity levels within the same strain and day.

${ }^{1}$ The calibrator consisted of samples taken at d 3 of incubation and always had a value equal to 1 . 
CQ7 samples after $3 \mathrm{~d}$ of incubation). The regulatory genes showed similar patterns of gene expression at the $3 \mathrm{pH}$ conditions tested, with different transcriptional profiles between the 3 strains. For the CQ8 strain, we observed the highest expression values at 6 and $9 \mathrm{~d}$ of incubation at $\mathrm{pH} 5.5$, with a decrease in expression levels over the following days. We observed a significant increase in expression of the regulatory genes at $6 \mathrm{~d}$ of incubation at $\mathrm{pH} 5.5$ in strain CQ103. In contrast, CQ7 strain showed the lowest expression of these genes at all $\mathrm{pH}$ levels tested. This was not surprising, because the CQ7 strain has shown a relatively low capacity to produce aflatoxins in cheese media (Casquete et al., 2017). Gallo et al. (2016) and Rodríguez et al. (2014) have demonstrated that mycotoxin biosynthetic gene expression might be strain-dependent. In addition, the production of mycotoxins is usually higher at low $\mathrm{pH}$ : Keller et al. (1997) have reported higher aflatoxin production by $A$. parasiticus at $\mathrm{pH} 4.0$ to 6.0 than at $\mathrm{pH}$ 7.0 and 8.0.

Figure 2 shows the effect of different temperatures $\left(30,25,20\right.$, and $\left.15^{\circ} \mathrm{C}\right)$ at $0.95 \mathrm{a}_{\mathrm{w}}$ and at $\mathrm{pH} 5.0$ on the relative expression of the aflatoxin biosynthesis genes (aftR, aflS, and aftP) by the A. flavus strains in synthetic cheese medium during an incubation period of $12 \mathrm{~d}$. In general, the regulatory genes showed similar patterns of gene expression at all temperatures tested, with different transcriptional profiles between the 3 strains. For the CQ8 strain, we observed the highest expression values on d 6 and 9 of incubation at $20^{\circ} \mathrm{C}$, with a decrease in expression levels over the following days; the aflS gene showed the highest levels of expression for this strain. Strain CQ103 showed a significant increase in expression of regulatory genes aftR and aftS at $6 \mathrm{~d}$ of incubation at $25^{\circ} \mathrm{C}$, whereas aflP was the most expressed gene for this strain at $20^{\circ} \mathrm{C}$ and $\mathrm{d} 9$ of incubation. In contrast, CQ7 showed an increase in expression of all 3 genes throughout the incubation period at $30^{\circ} \mathrm{C}$; aftR was most highly expressed. Previous study on these strains reported optimal aflatoxin production at 25 to $30^{\circ} \mathrm{C}$ at 2 and $4 \mathrm{~d}$ of incubation (Casquete et al., 2017). However, in the current study, samples taken from d 3 were used as calibrators for the expression studies. Therefore, we did not assay activation of transcription before d 6 of incubation. Temporal analysis of the expression of biosynthetic genes to predict aflatoxin production would be feasible only if the window between gene activation and phenotypic expression was long enough. Clearly, the quantitative components of optimal aflatoxin production and relative transcript levels for the biosynthetic pathway genes chosen for this study were not temporally consistent. Peromingo et al. (2017) found the highest expression values for the aftR and aflS genes at 25 and $20^{\circ} \mathrm{C}$ and $0.95 \mathrm{a}_{\mathrm{w}}$ by $A$. flavus on a dry-cured ham-based medium.

Table 2 shows the effect of different $\mathrm{a}_{\mathrm{w}}(0.99,0.95$, and 0.90 ) at $25^{\circ} \mathrm{C}$ and $\mathrm{pH} 5.0$ on the relative expression of the aflatoxin biosynthesis genes tested. For strain CQ8, we observed the highest expression values of the aflP gene at $0.90 \mathrm{a}_{\mathrm{w}}$, with a maximum value at $9 \mathrm{~d}$ of incubation. For strain CQ7, the aflP gene showed maximum expression at $0.99 \mathrm{a}_{\mathrm{w}}$ at the end of the incubation period (9 and $12 \mathrm{~d}$ ). Strain CQ7 did not grow at 0.90 $\mathrm{a}_{\mathrm{w}}, \mathrm{pH} 5.0$, and $25^{\circ} \mathrm{C}$. In contrast, in the CQ103 strain, the aftR and aflS genes exhibited higher levels of expression at $0.95 \mathrm{a}_{\mathrm{w}}$ and $\mathrm{d} 6$ of incubation. These results were consistent with those obtained by Casquete et al. (2017), in which the strains CQ7 and CQ103 were un-

Table 3. Effect of $\mathrm{pH}\left(5.0,5.5\right.$, and 6.0) on aflatoxin production $\left(\mu \mathrm{g} / \mathrm{cm}^{2}\right)$ by 3 Aspergillus flavus strains $10 \mathrm{~d}$ after the end of the lag phase ${ }^{1}$

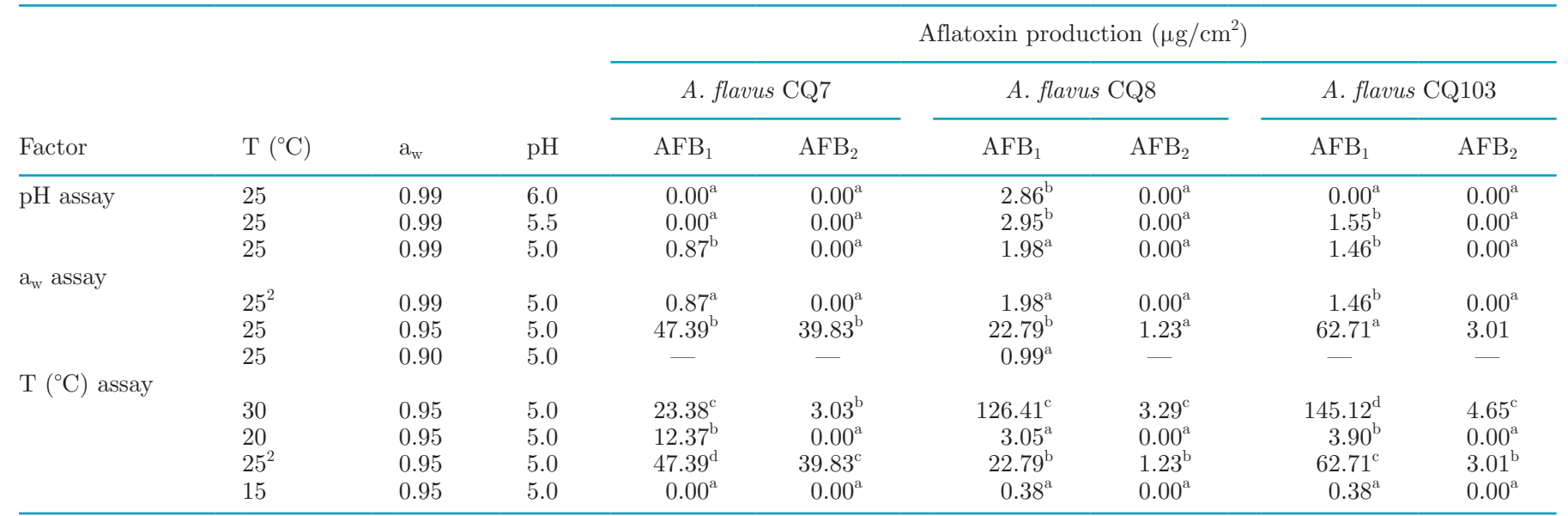

\footnotetext{
$\overline{\mathrm{a}-\mathrm{d}}$ Values with different superscript letters were significantly different $(P \leq 0.05)$ between conditions within the same strain.

${ }^{1} \mathrm{AFB}_{1}=$ aflatoxin $\mathrm{B}_{1} ; \mathrm{AFB}_{2}=$ aflatoxin $\mathrm{B}_{2} ; \mathrm{a}_{\mathrm{w}}=$ water activity; $\mathrm{T}=$ temperature.

${ }^{2}$ Data rows repeated for easier data comparison.
} 


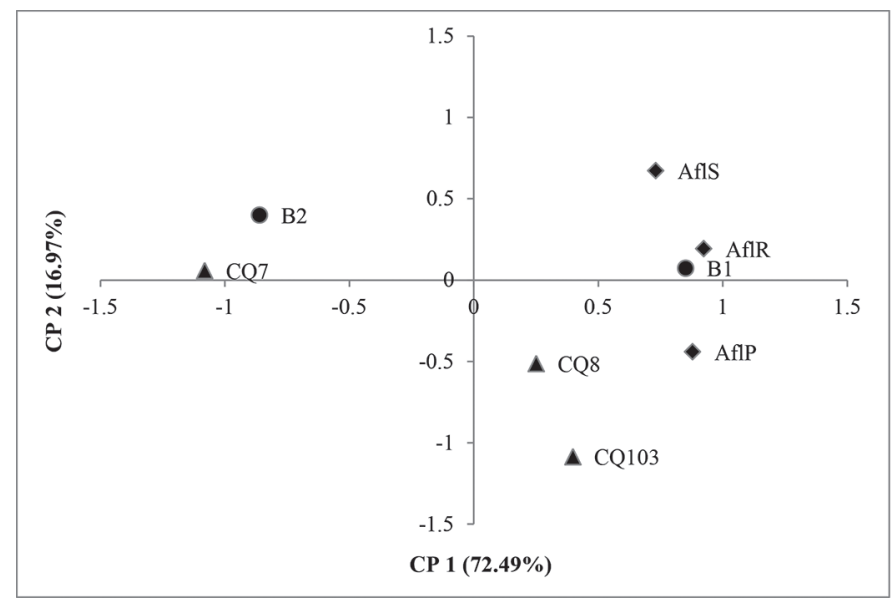

Figure 3. Principal component analysis of the relative expression of aflR, aflS, and aflP genes (diamonds) on a cheese-based medium by Aspergillus flavus strains CQ7, CQ8, and CQ103 and the levels of aflatoxin $\mathrm{B}_{1}$ (B1) and aflatoxin $\mathrm{B}_{2}$ (B2; circles) of the same samples determined after $10 \mathrm{~d}$ of incubation.

able to produce aflatoxins at $0.90 \mathrm{a}_{\mathrm{w}}$, but CQ8 showed production. However, the 3 strains used in Casquete et al. (2017) showed different levels of expression at 0.95 $\mathrm{a}_{\mathrm{w}}$, where the maximum aflatoxin accumulation was evident. Other authors have found a strong induction of the aflP gene by $A$. flavus at $0.90 \mathrm{a}_{\mathrm{w}}$ (Peromingo et al., 2017).

In general, the levels of expression of the 3 genes aflP, aftR, and aflS were much higher in the A. flavus CQ8 and CQ103 strains than in the CQ7 strain. Gene expression was affected by $\mathrm{pH}$, temperature, $\mathrm{a}_{\mathrm{w}}$, and interactions between these components. We observed the highest gene expression levels at $\mathrm{pH} 5.5$, temperature $25^{\circ} \mathrm{C}$ and $\mathrm{a}_{\mathrm{w}} 0.90$ to 0.99 ; optimal $\mathrm{a}_{\mathrm{w}}$ was straindependent.

\section{Correlations Between Aflatoxin Production and Temporal Expression of Biosynthetic Genes}

Figure 3 shows the results of the principal component analysis including the relative expression of aftR, aftS, and affP at $\mathrm{d} 9$ of incubation in combination with the amounts of $\mathrm{AFB}_{1}$ and $\mathrm{AFB}_{2}$ produced by the 3 strains of $A$. flavus on synthetic cheese medium after $10 \mathrm{~d}$ of incubation. The $\mathrm{AFB}_{1}$ and $\mathrm{AFB}_{2}$ content at d 10 of incubation are shown in Table 3. The aftR and aftS regulatory genes were located on the positive axis of main component 1 , defined by the production of $\mathrm{AFB}_{1}$, explaining $72.49 \%$ of the total variance; component 2 describes an additional $16.97 \%$ of the original variability of the data (Figure 3). The principal component analysis from $A$. flavus showed a clear relationship between the concentration of $\mathrm{AFB}_{1}$ and the relative temporal expression of the genes studied, but we found no association between the amounts of $\mathrm{AFB}_{2}$ and relative gene expression. These results agreed with those reported by Bernáldez et al. (2017) and Peromingo et al. (2017), who found a strong correlation between the temporal relative expression of regulatory genes aftR and aflS and the production of $\mathrm{AFB}_{1}$ by A. flavus.

\section{CONCLUSIONS}

The current study demonstrated that the relative expression of the biosynthetic genes aftR and aftS from 3 different strains of $A$. flavus, grown on model cheese medium, was related to phenotypic aflatoxin production. We observed different transcriptional profiles in the 3 aflatoxin-producing strains, related to their aflatoxin production. The relative expression of aftR and aftS from the aflatoxin biosynthetic pathway could be used to design and implement effective control strategies for avoiding aflatoxin production during the manufacture and storage of cheese.

\section{ACKNOWLEDGMENTS}

This work was funded by the Spanish Ministry of Economy (AGL2013-45729-P). The authors are grateful to M. Cabrero and J. Hernández Barreto (Nutrición y Bromatología, Escuela de Ingenierías Agrarias, Universidad de Extremadura, Badajoz, Spain) for technical assistance.

\section{REFERENCES}

Abdel-Hadi, A., M. Schmidt-Heydt, R. Parra, R. Geisen, and N. Magan. 2012. A systems approach to model the relationship between aflatoxin gene cluster expression, environmental factors, growth and toxin production by Aspergillus flavus. J. R. Soc. Interface 9:757-767.

Abdel-Hadi, A. M., D. P. Caley, D. R. F. Carter, and N. Magan. 2011. Control of aflatoxin production of Aspergillus flavus and Aspergillus parasiticus using RNA silencing technology by targeting aftD (nor-1) gene. Toxins (Basel) 3:647-659.

Arrus, K., G. Blank, D. Abramson, R. Clear, and R. A. Holley. 2005. Aflatoxin production by Aspergillus flavus in Brazil nuts. J. Stored Prod. Res. 41:513-527.

Astoreca, A., G. Vaamonde, A. Dalcero, A. J. Ramos, and S. Marin. 2012. Modelling the effect of temperature and water activity of Aspergillus flavus isolates from corn. Int. J. Food Microbiol. 156:60-67.

Baranyi, N., D. J. Despot, A. Palágyi, N. Kiss, S. Kocsubé, A. Szekeres, A. Kecskeméti, O. Bencsik, C. Vágvölgyi, M. Š. Klarić, and J. Varga. 2015. Identification of Aspergillus species in Central Europe able to produce G-type aflatoxins. Acta Biol. Hung. $66: 339-347$.

Barrios, M. J., L. M. Medina, M. G. Cordoba, and R. Jordano. 1997. Aflatoxin-producing strains of Aspergillus flavus isolated from cheese. J. Food Prot. 60:192-194.

Bernáldez, V., J. J. Córdoba, N. Magan, B. Peromingo, and A. Rodríguez. 2017. The influence of ecophysiological factors on growth, afl $R$ gene expression and aflatoxin $\mathrm{B}_{1}$ production by a type strain of Aspergillus flavus. Lebensm. Wiss. Technol. 83:283-291. 
Bhatnagar, D., J. W. Cary, K. Ehrlich, J. Yu, and T. E. Cleveland. 2006. Understanding the genetics of regulation of aflatoxin production and Aspergillus flavus development. Mycopathologia 162:155166.

Casquete, R., M. J. Benito, M. de Guía Córdoba, S. Ruiz-Moyano, and A. Martín. 2017. The growth and aflatoxin production of $\mathrm{As}$ pergillus flavus strains on a cheese model system are influenced by physicochemical factors. J. Dairy Sci. 100:6987-6996.

De Santi, M., M. Sisti, E. Barbieri, G. Piccoli, G. Brandi, and V. Stocchi. 2010. A combined morphologic and molecular approach for characterizing fungal microflora from a traditional Italian cheese (Fossa cheese). Int. Dairy J. 20:465-471.

Gallo, A., M. Solfrizzo, F. Epifani, G. Panzarini, and G. Perrone. 2016. Effect of temperature and water activity on gene expression and aflatoxin biosynthesis in Aspergillus flavus on almond medium. Int. J. Food Microbiol. 217:162-169.

Georgianna, D. R., and G. A. Payne. 2009. Genetic regulation of aflatoxin biosynthesis: From gene to genome. Fungal Genet. Biol. 46:113-125.

Groopman, J. D., and T. W. Kensler. 2005. Role of metabolism and viruses in aflatoxin-induced liver cancer. Toxicol. Appl. Pharmacol. 206:131-137.

Hernández-Hierro, J. M., R. J. Garcia-Villanova, P. R. Torrero, and I. M. T. Fonseca. 2009. Aflatoxins and ochratoxin A in red paprika for retail sale in Spain: Occurrence and evaluation of a simultaneous analytical method. Czech J. Food Sci. 27:361-365.

Keller, N. P., C. Nesbitt, B. Sarr, T. D. Phillips, and G. B. Burow 1997. $\mathrm{pH}$ regulation of sterigmatocystin and aflatoxin biosynthesis in Aspergillus spp. Phytopathology 87:643-648.

Livak, K. J., and T. D. Schmittgen. 2001. Analysis of relative gene expression data using real-time quantitative PCR and the $2^{-\Delta \Delta C T}$ method. Methods 25:402-408.

Medina, A., A. Rodríguez, Y. Sultan, and N. Magan. 2015. Climate change factors and Aspergillus flavus: Effects on gene expression, growth and aflatoxin production. World Mycotoxin J. 8:171-179.

Molyneux, R. J., N. Mahoney, J. H. Kim, and B. C. Campbell. 2007. Mycotoxins in edible tree nuts. Int. J. Food Microbiol. 119:72-78.

Peromingo, B., M. Rodríguez, J. Delgado, M. J. Andrade, and A. Rodríguez. 2017. Gene expression as a good indicator of aflatoxin contamination in dry-cured ham. Food Microbiol. 67:31-40.

Rodríguez, A., Á. Medina, J. J. Córdoba, and N. Magan. 2014. The influence of salt $(\mathrm{NaCl})$ on ochratoxin A biosynthetic genes, growth and ochratoxin A production by three strains of Penicillium nor- dicum on a dry-cured ham-based medium. Int. J. Food Microbiol. 178:113-119.

Rodríguez, A., M. Rodríguez, M. I. Luque, A. Martin, and J. J. Córdoba. 2012. Real-time PCR assays for detection and quantification of aflatoxin-producing molds in foods. Food Microbiol. 31:89-99.

Schmidt-Heydt, M., A. Abdel-Hadi, N. Magan, and R. Geisen. 2009 Complex regulation of the aflatoxin biosynthesis gene cluster of Aspergillus flavus in relation to various combinations of water activity and temperature. Int. J. Food Microbiol. 135:231-237.

Schmidt-Heydt, M., C. E. Rüfer, A. Abdel-Hadi, N. Magan, and R. Geisen. 2010. The production of aflatoxin $\mathrm{B}_{1}$ or $\mathrm{G}_{1}$ by Aspergillus parasiticus at various combinations of temperature and water activity is related to the ratio aflS to aftR expression. Mycotoxin Res. 26:241-246.

Sweeney, M. J., P. Pàmies, and A. D. W. Dobson. 2000. The use of reverse transcription-polymerase chain reaction (RT-PCR) for monitoring aflatoxin production in Aspergillus parasiticus 439. Int. J. Food Microbiol. 56:97-103.

Taniwaki, M. H., A. D. Hocking, J. I. Pitt, and G. H. Fleet. 2001. Growth of fungi and mycotoxin production on cheese under modified atmospheres. Int. J. Food Microbiol. 68:125-133.

Visentin, I., V. Montis, K. Döll, C. Alabouvette, G. Tamietti, P. Karlovsky, and F. Cardinale. 2012. The transcription of genes in the biosynthetic pathway for fumonisin mycotoxins is epigenetically and differentially regulated in the fungal maize pathogen Fusarium verticillioides. Eukaryot. Cell 11:252-259.

Wogan, G. N. 1992. Molecular epidemiology in cancer risk assessment and prevention: Recent progress and avenues for future research. Environ. Health Perspect. 98:167-178.

Yu, J., N. D. Fedorova, B. G. Montalbano, D. Bhatnagar, T. E. Cleveland, J. W. Bennett, and W. C. Nierman. 2011. Tight control of mycotoxin biosynthesis gene expression in Aspergillus flavus by temperature as revealed by RNA-Seq. FEMS Microbiol. Lett. 322:145-149.

Zhang, F., Z. Guo, H. Zhong, S. Wang, W. Yang, Y. Liu, and S. Wang. 2014. RNA-Seq-based transcriptome analysis of aflatoxigenic Aspergillus flavus in response to water activity. Toxins (Basel) $6: 3187-3207$.

Zinedine, A., C. Juan, J. M. Soriano, J. C. Moltó, L. Idrissi, and J. Mañes. 2007. Limited survey for the occurrence of aflatoxins in cereals and poultry feeds from Rabat, Morocco. Int. J. Food Microbiol. 115:124-127. 